\title{
Online learning by using WhatsApp to improvestudents 'writing achievement in recount text at the first grade of SMAN 7 Bandar Lampung
}

\author{
Sakinah $^{1}$, Ari Nurweni ${ }^{2}$, Flora Nainggolan ${ }^{3}$ \\ FKIP Universitas Lampung, Jl. Prof. Dr. Soemantri Brojonegoro No.1, Bandar Lampung ${ }^{1,2,3}$ \\ Correspondence e-mail: $\underline{\text { sakinah.zarifin@gmail.com }}$
}

\begin{abstract}
Theobjectives of this research are to find out whether there is any significant improvement on students 'writing achievement by using online learning activity by using WhatsApp and to investigate students 'perception of it. This is a quantitative research.The population of the sample was thirty two students of the X MIA 6 of SMAN 7 Bandar Lampung in the academic year 2020/2021. The data were collected by using writing test and questionnaire. The data were analyzed by using Paired Samples T-Test and descriptive statistics. It is shown that there was statistically significant improvement of the students 'writing achievement after they were taught through online learning by WhatsApp group chat. Moreover, it could be seen from the computation of Paired Samples T-Test where the T-value $(17,576)$ was higher than t-table with the significance level was $0.00<0.05$. The result of this research indicates that there is significant improvement in all aspects of students 'writing achievement.This suggests that online learning activity by using WhatsApp can be used as a strategy to improve the students' writing achievement.
\end{abstract}

Keywords: Whatsapp, online learning, writing.

\section{INTRODUCTION}

Writing is one of the important subjects that students need to learn. Siddiqui and Sing (2015) stated to master writing achievement, the writer needs to express the feelings into meaningful form through a sentence. According to Brown (2001), writing is how a person communicates his or her thoughts and feelings by visible signs, understandable not only for himself but also for other people. It is considered success if one utters the feelings and thoughts into written form from words into sentences and sentences into a meaningful paragraph.

However, it does not happen the same way. It is supported by Husna et al (2013) who found that one of the students 'difficulties in writing is students are still unable to transfer and develop their ideas into a written form well in composing a text. To create good EFL writing, becomes a great challenge and it is difficult to achieve since students face many problems in writing especially regarding to fully understand and include all five aspects of writing. Jacobs et al,. (1981) classifies five important elements in writing. Those elements are content, organization, vocabulary, grammar, and mechanics. Based on the review of past studies, Mastan et al. (2017) concluded that among the common problems faced by second-language writers of English include the inability to generate ideas in the L2, inaccurate use of grammar, insufficient vocabulary as well as lack of the other things in aspect of writing 
Taking the case of teaching writing, teachers always attempt to apply different approaches to decrease the common problems appeared one of which is by using online learning. Sabah and Hacene (2016) state that adopting online learning has a good evidence as it could lower learners' psychological barriers to enable them expressing their opinions freely and to communicate actively on the internet and that it could also enhance their critical thinking, problem solving and communication skills.

Some studies regarding the use of online learning by using WhatsApp have been conducted. The first research is the most frequently reported satisfying aspect of online learning was its flexibility in learning, where students were able to study at their own pace and at the time convenient to them (Bentley et al,.2003). Then, based on Kabilan et al., (2010) it showed that the survey carried out 300 undergraduate students at University Sains Malaysia (USM), Penang. It was found that the students believed FB could be utilized as an online environment to facilitate the learning of English. Similar to findings in other studies, by Janet et al,.(2004). The study investigated the experiences of online learning especially in students' perspective. The sample was focused on the students' experiences in a technology-enhanced teaching and learning process. Students' overall satisfaction with online learning was found to be slightly positive in this study.

\section{METHODS}

This research used quantitative research design as the research methodology. The aim was to find out whether there was any significant improvement of students' writing achievement after online learning by using WhatsApp. The population of the research was students in the first grade of SMA N 7 Bandar Lampung. The sample was 32 students in X MIA 6. This study used random sampling technique. The data were collected from the speaking tests (pre-test and post-test).The data of the tests were then analyzed by using Paired Samples T-Test in SPSS version 20.

\section{RESULTS AND DISCUSSIONS}

This section presents the result of data analysis. For the test result, the improvement in each aspect can be seen from the following table:

Table 3.1 the improvement of the students' writing achievement

\begin{tabular}{cccccc}
\hline $\begin{array}{c}\text { Aspects of } \\
\text { Writing }\end{array}$ & $\begin{array}{c}\text { Mean Score of Pre- } \\
\text { Test }\end{array}$ & $\begin{array}{c}\text { Mean Score of Post- } \\
\text { Test }\end{array}$ & $\begin{array}{c}\text { Gain } \\
\text { Score }\end{array}$ & $\begin{array}{c}\text { Maximum } \\
\text { Score }\end{array}$ & Percentage \\
\hline Content & 13,25 & 20,93 & 4,57 & 30 & $21,2 \%$ \\
\hline Organization & 13,25 & 16,17 & 2,92 & 20 & $11 \%$ \\
\hline Vocabulary & 14,01 & 16,14 & 2,12 & 20 & $10,6 \%$ \\
\hline Grammar & 14,12 & 17,5 & 3,37 & 25 & $13,48 \%$ \\
\hline Mechanics & 2,87 & 3,93 & 1,06 & 5 & $15,93 \%$ \\
\hline
\end{tabular}


Table 4.1. above provides the data of students 'writing score in pre-test, score in post-test, gain score, and maximum score of each aspect of writing. According to the table, there is improvement on students 'writing achievement in every aspect of writing. The highest gain score belongs to the content $(4,57)$ with the percentage of $21,2 \%$, followed by organizations which is shown (2.92) with $11 \%$ in the percentage. Then, the mean score of vocabulary $(2,12)$, grammar $(3,37)$, and mechanics $(1,06)$ also improved with the percentage at every aspect 10,6\%, 13,48\%, 15,93\%

To find out whether the improvement was significant or not, Paired Sample T-Test in SPSS version 20 was used in this research. The following table shows the result of Paired Samples T-Test.

\begin{tabular}{|c|c|c|c|c|c|c|c|c|c|}
\hline \multicolumn{10}{|c|}{ Paired Samples Test } \\
\hline & & \multicolumn{5}{|c|}{ Paired Differences } & \multirow[t]{3}{*}{$\mathrm{t}$} & \multirow[t]{3}{*}{ df } & \multirow{3}{*}{$\begin{array}{c}\text { Sig. } \\
(2- \\
\text { tailed) }\end{array}$} \\
\hline & & \multirow[t]{2}{*}{$\begin{array}{c}\mathrm{Me} \\
\text { an }\end{array}$} & \multirow[t]{2}{*}{$\begin{array}{l}\text { Std. } \\
\text { Deviat } \\
\text { ion }\end{array}$} & \multirow[t]{2}{*}{$\begin{array}{l}\text { Std. } \\
\text { Error } \\
\text { Mean }\end{array}$} & \multicolumn{2}{|c|}{$\begin{array}{c}\text { 95\% Confidence } \\
\text { Interval of the } \\
\text { Difference }\end{array}$} & & & \\
\hline & & & & & Lower & Upper & & & \\
\hline \multicolumn{10}{|c|}{$\mathrm{P}$} \\
\hline \multirow{2}{*}{$\begin{array}{l}\mathrm{a} \\
\mathrm{i} \\
\mathrm{r}\end{array}$} & PostTest - & $\begin{array}{r}16 . \\
578\end{array}$ & \multirow{3}{*}{$\begin{array}{r}5.335 \\
68\end{array}$} & \multirow{3}{*}{.94322} & \multirow{3}{*}{$\begin{array}{r}14.654 \\
41\end{array}$} & \multirow{3}{*}{$\begin{array}{r}18.501 \\
84\end{array}$} & $\begin{array}{r}17 . \\
57\end{array}$ & \multirow{3}{*}{31} & \multirow{3}{*}{.000} \\
\hline & PreTest & & & & & & 6 & & \\
\hline 1 & & & & & & & & & \\
\hline
\end{tabular}

Table 3.2 above provides evidence that the result shows that the two tailed significance is 0.000 . It indicates that $\mathrm{H} 1$ is accepted because 0.00 is less than $0.05(0.00<0.05)$. It proves that there is significant improvement on students' writing achievement after the implementation of online learning activity by using WhatsApp.

\section{Discussions}

The finding of this research shows that students' skill in recount text has improved after the implementation of online learning activity by using WhatsApp at the first grader of high school especially in recount text. It is shown that there is improvement in students' writing recount from 58,85 to 75,75 . Then, it was found out that the significant level is 0,000 which was lower than 0,05 . Therefore, it indicates that online learning activity by using WhatsApp can significantly improve students' writing achievement. As stated by Dumanauw (2016), WhatsApp is a medium to improve students in writing achievement. Therefore, this research supports the finding from the previous 
research that online learning by using WhatsApp can improve students' recount text writing achievement especially in senior high school students.

Moreover, the improvements was shown in these aspects of writing were content, organization, vocabulary, grammar, mechanic. Based on the result, it was found out that content had the highest improvement among the other aspects of writing. The mean score of pre-test in aspect of content was 13,25 and the mean score in post-test was 20,93. The researcher had been trying to figure out on why content had the highest improvement among the others.

In line with what the researcher had observed, the students were not able to express their ideas into written form including all five aspects of writing in it. They seemed to have confusion in writing a sentence or paragraph with minimum words given by the researcher in which it turned out to be unsuitable. After giving some explanations including giving a picture of recount text that was categorized in every color for each aspect of writing and also having discussion, the students started to be able analyzing the form and words while it turned out they became more relax and enjoyed the activities in WhatsApp It was also noticed at the first meeting of a treatment that those students who had no idea with the English word and the correct form in recount text, used the suitable form and right words in their writing. This shown that WhatsApp helped the lower level students to learn from the other students as they had opportunities to look at their writings and to learn from it.

Other than that, it can be seen from the table that students also had some improvement in aspect of organization after all three treatments were given. The students were able to make paragraph accordingly one to another statement. The improvement of the content aspect was also shown and became the one which had the highest improvement after the implementation of online learning by using WhatsApp since it could enhance students' participation actively. It was seen from the discussion happening in WhatsApp that some students did not have a clear idea in generating it into written form. Therefore, it was providing the students with an opportunity for practicing the language for free, to learn better, and also an opportunity for students to synchronize their opinions with others. By using WhatsApp, it makes them easier to communicate with each other without freedom limitations since it relates to the experiences of the students. Therefore, Mona (2017) states that WhatsApp can make them enthusiastic to learn writing especially in a recount text since WhatsApp helps to facilitate the students in discussion, and helps students to overcome their fear of using the language and the students feel enthusiastic to use WhatsApp as a learning medium.

While giving the treatment, the students were provided with materials and examples of recount text picture. They were also asked to discuss the topic and to write in which was related to the topic. But one of the other things should be considered playing an important role in writing recount text is mechanic. At the first time, it was shown that the students did not consider mechanic as an important aspect. They wrote paragraph and had a few full-stops without giving a coma, apostrophe and other things in a sentence. It could affect the reader's experience to be able getting the information of the writer's work. But after giving some feedbacks and relying on the materials given, the students were able to work on improving the aspect of mechanic in their writing. 


\section{CONCLUSION AND SUGGESTIONS \\ Conclusions}

Online learning by using WhatsApp group chat significantly improves students' writing achievement in recount text. It could be seen from the improvements of students' writing score in the pre-test and post-test. Other than that, it can be seen from the value of two tailed is significance is 0.00 which is lower than 0.05 . It also enables the students to interact whether to the friends or to the teacher since WhatsApp can enhance the accessibility, encourage cooperation, and giving motivation to take a part actively in every assignment and also it is convenient and easy for the students in the group to express their ideas. As a result, WhatsApp can be used as a medium in online learning activity since the improvement was seen in all aspects of writing, which the highest one belongs to content.

\section{Suggestions}

There are several suggestions or recommendations regarding to this research especially in writing achievement. First, the teachers are required to set the goals clear in each activity. In order to achieve that goal, the teachers need to make sure that the students are comfortable enough to participate actively especially in online learning by using WhatsApp. Then the teachers should consider the time for each meeting to optimize the learning result. For further researchers, it is suggested to try conducting this research in another level of education. It is also recommended to do the research in longer duration so it will give a better finding.

\section{REFERENCES}

Bentley, G.W., Cook, P.P., Davis, K., Murphy, M.J., Berding, C.B. (2003). RN to BSN program: Transition from traditional to online delivery. Nurse educator, 28 (3), 121-126.

Brown, D.H. (2001). Teaching by principles: An interactive approach to language pedagogy-2nd edition. New York: Longman.

Dumanauw (2016). The use of WhatsApp application to teach writing of recount text. Pontianak: Tanjung Pura University.

Husna, L., Zainil, and Rozimela, Y. (2013). An analysis of students 'writing skill in descriptive text at grade XI IPA 1 of MAN 2 Padang. West Sumatra: Journal English Language Teaching (ELT) Volume 1 No 2.

Jacobs, H. L., Zinkgraf, S. A., Wormuth, D. R., Hartfiel, V. F., and Hughey, J. B. (1981). Testing ESL composition: A practical approach. Massachusetts: Newbury House.

Janet W.H. Sit, Joanne W.Y. Chung, Meyrick C.M. Chow, Thomas K.S. Wong. (2004). Experiences of online learning: students' perspective. Nurse Education Today, 25,140-147

Kabilan, M. K., Ahmad, N., \& Abidin, M.J.Z. (2010). Facebook: An online environment for learning of English in institutions of higher education? The Internet and Higher Education, 13 (4), 179-187. doi:10.1016/j.iheduc.2010.07.003.

Mastan, M. E., Nooreiny Maarof\&Mohamed Amin Embi. (2017). The effect of writing strategy instruction on ESL intermediate proficiency learners' writing performance. Journal of Educational Research and Review, 5(5): 71-78. 
Mona, H. M. (2017). Using WhatsApp to Enhance Students' Learning of English Language "Experience to Share". Journal ofHigher Education Studies, 7 (4), 74-87.

Sabah, K., and Hacene, H. (2016). Blended learning in academic writing: realities and perspectives. Journal of Information Technology Education, 27 171-196.

Siddiqui, S., and Sing, T. (2015). Social Media its Impact with Positive and Negative Aspects. International Journal of Computer Applications Technology and Research, 5, 71-75. 